\title{
Haematological and biochemical profiles of WAD goats fed graded levels of bitter leaf (Vernonia amygdalina) meal
}

${ }^{1}$ Olosunde, A. O., ${ }^{2}$ Odeyinka, S. M. and ${ }^{1}$ Oyedele, O. J.

${ }^{1}$ Bioresources Development Centre Ogbomoso, National Biotechnology Agency, Abuja, Klm 5, Iresaapa/Ogbomoso Road, Onipanu, Ogbomoso, Oyo state, Nigeria

${ }^{2}$ Department of Animal Sciences, Obafemi Awolowo University, Ile-Ife, Osun State.

Abstract

*Corresponding author: mrbgodveng@gmail.com

Bitter leaf is an underutilized manageable size shrub in Nigeria despite its numerous nutritional benefits, economic value and potential as a dry season feed source for ruminant animals. This study was carried out to determine the haematological and biochemical profiles of West African Dwarf (WAD) goats fed graded levels of bitter leaf (Vernonia amygdalina) meal (BLM). Twenty-four WAD goats of both sexes and 5-7 months old were randomly allotted to four treatments of graded levels of BLM $(0 \%$ BLM (Control Diet), $15 \%$ $B L M, 30 \%$ BLM and 45\% BLM diets) in a completely randomized design. The diets were used as supplements to a basal ration of Panicum maximum. The feeding trial lasted 20 weeks. The analysis of blood components, red blood cell (RBC), white blood cell (WBC) and parked cell volume $(P C V)$ counts showed that there were no significant $(P>0.05)$ differences in each of these parameters among the goats fed experimental diets. There were no significant differences in the albumin, alkaline phosphatase, cholesterol, creatinine, globulin, total protein and urea levels of the animals fed the different levels of bitter leafmeal $(p>0.05)$. The result of the serum glucose of goats fed 30\% BLM and 45\% BLM was significantly $(p<0.05)$ lower than that of $C D$. It is concluded that feeding of bitter leaf meal at the different levels had no adverse effect on the haematological and biochemical profiles of WAD goats except in the reduction of serum glucose in animals fed above 15\% bitter leaf meal.

Keywords: Vernonia amygdalina, haematological characteristic, biochemical parameters, WAD goat

\section{Des Profils hématologiques et biochimiques de chèvres WAD nourries à des aliments} de Farine de feuilles amères (Vernonia amygdalina)

${ }^{1}$ Olosunde, A. O., ${ }^{2}$ Odeyinka, S. M. and ${ }^{1}$ Oyedele, O. J.

${ }^{\prime}$ Bioresources Development Centre Ogbomoso, National Biotechnology Agency, Abuja, Klm 5, Iresaapa/Ogbomoso Road, Onipanu, Ogbomoso, Oyo state, Nigeria

${ }^{2}$ Department of Animal Sciences, Obafemi Awolowo University,

Ile-Ife, Osun State.

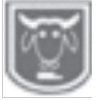

*Corresponding author: mrbgodveng@gmail.com.

\section{Résumé}

La feuille amère est un arbuste de taille gérable sous-utilisé au Nigéria malgré ses nombreux avantages nutritionnels, sa valeur économique et son potentiel en tant que source d'alimentation de saison sèche pour les ruminants. Cette étude a été réalisée pour déterminer les profils hématologiques et biochimiques de chèvres naines d'Afrique de l'Ouest (WAD) nourries à des aliments de farine de feuilles amères(le 'BLM') (Vernonia amygdalina). Vingtquatre chèvres WAD des deux sexes et âgées de 5 à 7 mois ont été attribuées au hasard à quatre traitements de niveaux gradués de BLM (0\% BLM (régime témoin), 15\% BLM, 30\% 


\section{Haematological and biochemical profiles of WAD goats fed bitter leaf (Vernonia amygdalina)}

BLM et 45\% BLM) dans conception aléatoire. Les régimes ont été utilisés comme suppléments à une ration basale de Panicum maximum. L'essai d'alimentation a duré 20 semaines. L'analyse des comptages des composants sanguins, des globules rouges (le 'RBC'), des globules blancs (le 'WBC') et du volume de cellules en stationnement (le 'PCV') a montré qu'il n'y avait pas de différence significative $(P>0,05)$ dans chacun de ces paramètres parmi les chèvres nourries avec des régimes expérimentaux. Il n'y avait pas de différences significatives dans les taux d'albumine, de phosphatase alcaline, de cholestérol, de créatinine, de globuline, de protéines totales et d'urée des animaux nourris avec les différents niveaux de farine de feuilles amères $(p>0,05)$. Le résultat du glucose sérique des chèvres nourries à $30 \%$ de BLM et $45 \%$ de BLM était significativement $(p<0,05)$ inférieur à celui de CD. Il est conclu que l'alimentation de farine de feuilles amères à différents niveaux n'a eu aucun effet indésirable sur les profils hématologique et biochimique des chèvres WAD, sauf dans la réduction de la glycémie chez les animaux nourris à plus de 15\% de farine de feuilles amères.

Mots clés :Vernonia amygdalina, caractéristique hématologique, paramètres biochimiques, chèvre

\section{Introduction}

Bitter leaf (Vernonia amygdalina) is a manageable size shrub that is available during dry season, its nutritional, economic value and potential as a dry season feed source for ruminant animals is underutilized. The leaves are used for human consumption, suggesting that the excess may be utilized as feed (Daodu and Babayemi, 2009). The leaf extract of V. amygdalina is known to enhance the immune systems through cytokines regulation. Studies by Farombi and Owoeye (2011) implicated extracts of V. amygdalina to be rich in phytochemicals like saponins alkaloids, terpenes, steroids, coumarins, flavonoids, phenolics, lignans, xanthones, anthraquinones edotides and sesquiterpenes which elicit biological effects including cancer chemoprevention, among others. Despite all these potentials, bitter leaf contains some anti-nutritional components that can have advantageous or adverse effect on human and animal health depending on the quantity consumed (Sugano et al., 1993). The measurement of blood parameters is one of the most valuable tools in studying the effects of nutrition, age, sex, breed, chemical agents and radiation in animals (Olayeni et al., 2006) because the blood is a crucial indicator of the physiological and pathological state of an organism. Bawala et al. (2008) suggested that nutritional studies should not be limited to performance, carcass quality and protein intake alone, but the effect on blood constituents is also very relevant. Haematological and biochemical studies could help in realistic evaluations of the many practice, nutrition and diagnosis of health conditions of animals (Ahmed et al., 2009; Hassan et al., 2012; Okoruwa and Ikhimioya, 2014). This study therefore seeks to evaluate haematological and biochemical profiles of (WAD) goats fed graded levels of bitter leaf (Vernonia amygdalina) meal (BLM).

\section{Materials and methods \\ Experimental site}

The experiment was carried out at the Sheep and Goat Unit of the Teaching and Research Farm, Obafemi Awolowo University, IleIfe, Osun State. The farm is approximately between latitudes $7^{\circ} 31^{\prime} \mathrm{N}$ and $7^{\circ} 33^{\prime} \mathrm{N}$; and longitudes $4^{\circ} 33^{\prime} \mathrm{E}$ and $4^{\circ} 34^{\prime} \mathrm{E}$. It is within the tropical rainforest. Twenty-four West African Dwarf(WAD) weaner goats of both sexes were used in this experiment. The ages of the animals were between 5 and 7 months. 


\section{Olosunde, Odeyinka and Oyedele}

Management of experimental animals

The goats were quarantined, treated with oxycare antibiotic injection for 3 days, dewormed with levamizole and given ivomec injection to guard against endoparasites and ectoparasites. Also, they were treated for pneumonia and vaccinated against peste des petits ruminante (PPR) as a routine practice prior to the commencement of the experiment. The animals were randomly allotted to four treatments in a completely randomized design with six goats per treatment and provided fresh feed and water daily. The experiment lasted for a period of 20 weeks.

Preparation of experimental diet

The Vernonia amygdalina leaves for this study were harvested from the cut branches of the planted shrub within the environment of the Teaching and Research farm, Obafemi Awolowo University, Ile-Ife. Samples were air dried for two days and sun dried on concrete slabs for a day. The samples were ground prior to its incorporation in goat diets. Four concentrate diets comprising $0,15,30$ and $45 \%$ of Bitter Leaf (Vernonia amygdalina) Meals (BLM) were compounded and fed to the goats as supplements to a basal ration of guinea grass (Panicum maximum) (Table 1 ). The goats were fed based on $3 \%$ of their body weights. The proximate composition of the BLM sample was determined by standard methods (AOAC, 2000).

Table 1: Composition of experimental diets with different levels of BLM

\begin{tabular}{lllll}
\hline Ingredients & $0 \%$ BLM & $15 \%$ BLM & $30 \%$ BLM & $45 \%$ BLM \\
\hline Corn bran & 45.00 & 30.00 & 15.00 & - \\
Bitter leaf meal & - & 15.00 & 30.00 & 45.00 \\
Brewers dried grain & 30.00 & 30.00 & 30.00 & 30.00 \\
Palm kernel cake & 22.50 & 22.50 & 22.50 & 22.50 \\
Bone Meal & 1.50 & 1.50 & 1.50 & 1.50 \\
Salt & 0.50 & 0.50 & 0.50 & 0.50 \\
Vitamin Premix & 0.50 & 0.50 & 0.50 & 0.50 \\
Total & 100.00 & 100.00 & 100.00 & 100.00 \\
Calculated \% Crude & 14.70 & 17.14 & 19.58 & 22.01 \\
protein & & & &
\end{tabular}

$0 \% \mathrm{BLM}=$ Control diet ( $0 \%$ bitter leaf meal), $15 \%$ BLM $=15 \%$ bitter leaf meal inclusion, $30 \%$ $\mathrm{BLM}=30 \%$ bitter leaf meal inclusion, $45 \% \mathrm{BLM}=45 \%$ bitter leaf meal inclusion, $\mathrm{CP}=$ Crude protein

\section{Blood sampling}

At $17^{\text {th }}$ week of the study, blood samples through the jugular vein were collected from experimental animals in each of the four dietary treatment groups in the morning before feeding and to measure the hematological and biochemical properties. Each blood sample was emptied into two sets of well labeled sample bottles, one containing ethylene diamine tetra-acetate (EDTA) as anti-coagulant while the other contained no anti-coagulant. The sample containing anti-coagulant was used for the analysis of hematological traits (parked cell volume (PCV), red blood cell (RBC) and white blood cell (WBC) counts) while sample without anti-coagulant was used to analyse the serum biochemical profiles (creatinine, total protein, glucose, bilirubin, alkaline phosphatase, cholesterol, albumin and urea) of the (WAD) goats per treatment. The serum metabolites were determined according to Randox procedure of chemical analysis (2010). The readings were carried out using photo spectrometer in the laboratory. 


\section{Statistical analysis}

Data obtained were statistically analyzed with the General Linear Model of SAS (2008) and the Duncan New Multiple Range Test option of SAS (2008) was used to detect significant differences among means.

\section{Results and discussion}

The chemical composition of bitter leaf meal (BLM) and Panicum maximum used in the experimental diets is shown in Table 2. The dry matter and ash content of bitter leaf meal were higher than that of $P$. maximum while $P$. maximum had higher organic matter, crude fibre, ether extract and nitrogen free extract content. The result of the chemical composition of BLM and $P$. maximum used in the experimental diets shows that the crude protein content of bitter leaf meal was quite high compared to that of $P$. maximum and comparable crude protein range of $18-21.50 \%$ for bitter leaf was reported by Bonsi et al. (1995), Okoli et al. (2003), Fajemisin et al. (2009) and Owen (2011). However, a high value of $32.60 \%$ from $V$. amygdalina extract was reported by Aletor et al. (2002). The difference in values may be as a result of stage of growth, processing method and season of harvesting.

Table 2: Chemical composition of bitter leaf meal and Panicum maximum

\begin{tabular}{lll}
\hline Parameter & Bitter leaf meal & Panicum maximum \\
\hline Dry Matter (\%) & 86.84 & 20.61 \\
Analysis \% of DM & & \\
Organic Matter & 85.35 & 90.16 \\
Crude Protein & 25.25 & 7.36 \\
Crude fibre & 11.37 & 28.78 \\
Ether Extract & 19.49 & 24.44 \\
Ash & 15.65 & 8.45 \\
Nitrogen free extracts & 29.25 & 30.24 \\
\hline
\end{tabular}

DM: Dry matter

Table 3 shows the haematological parameters of WAD goats fed experimental diets. There was no significant $(\mathrm{P}>0.05)$ differences recorded across the treatment groups for RBC, WBC and PCV. RBC counts obtained in this study were within the range of $11-18 \times 10^{3} / \mathrm{mm}^{3}$ for WAD goats reported by Jean (1992). The mean WBC observed in this study was higher than the normal physiological range of 4.0-12.0 $\mathrm{x} 10^{3} / \mathrm{mm}^{3}$ and $11.72-13.27 \times 10^{3} / \mathrm{mm}^{3}$ for goat reported by Jain (1993) and Olubunmi et al. (2005), respectively. However, following the report of Yusuf et al. (2012) WBC fell within the normal range (14.55-
$29.60 \mathrm{x} 10 / \mathrm{L})$ for healthy goats. The observed PCV values fell within the range of $21.0-36.9 \%$ reported for clinicallyhealthy WAD goats (Merck, 2011; Imaseun, 2012 and Yusuf et al., 2012) but above the values of 19.4-20.5 and 24.8 reported by Nwakpu and Uchewa (2014) and Amakiri (1981), respectively. The observed PCV values were lower than (35.40-36.77\%) reported by Odoemelam et al. (2014). Aikhuomobhogbe and Orheruata (2006) asserted that lower PCV results in anemia reduced oxygen carryingcapacity of blood, increased pulse rate and consequently heart failure. 
Olosunde, Odeyinka and Oyedele

Table 3: Hematological parameters of WAD goats fed different levels of bitter leaf meal

\begin{tabular}{lcccccc}
\hline Parameter & CD & $15 \%$ BLM & $30 \%$ BLM & $45 \%$ BLM & SEM & PROB \\
\hline RBC $\left(\times 10^{6} / \mathrm{mm}^{3}\right)$ & 14.56 & 13.72 & 16.08 & 13.94 & 0.91 & 0.84 \\
WBC $\left(\times 10^{3} / \mathrm{mm}^{3}\right)$ & 24.80 & 25.68 & 16.05 & 20.95 & 2.46 & 0.56 \\
PCV $(\%)$ & 33.67 & 31.00 & 28.33 & 26.33 & 1.60 & 0.45 \\
\hline
\end{tabular}

$\mathrm{a}, \mathrm{b}, \mathrm{c}, \mathrm{d}$ : Means within each row with different superscript are significantly different ( $\mathrm{p} \square 0.05)$

Hence, it can be asserted that the experimental animals were within the normal range that can maintain the animal of normal PCV. Esonu et al. (2001) stated that, haematological constituents reflect the physiological responsiveness of the animal to its internal and external environment, which include feed and feeding. This present study showed that feeding Vernonia amygdalina at different levels supplemented with concentrate had no deleterious effect on the levels of RBC, WBC and PCV counts in the blood of weaner goats. Table 4 shows the serum biochemistry of WAD goats fed different levels of bitter leaf meal. Serum parameters have been reported to be important in the proper maintenance of the osmotic pressure between the circulating fluid and the fluid in the tissue space so that the exchange of materials between the blood and cell could be facilitated (Isidahomen et al., 2012). There were no significant differences in the albumin, alkaline phosphatase, cholesterol, creatinine, globulin, total protein and urea levels of the animals fed the different levels of bitter leaf meal $(\mathrm{P}>0.05)$. The serum albumin content $(\mathrm{g} / \mathrm{dl})$ do not differ significantly $(\mathrm{P}>0.05)$ among treatment groups. There was significant difference in the level of serum glucose of the animals fed different levels of bitter leaf meal.

Table 4: Serum biochemistry of WAD goats fed different levels of bitter leaf meal

\begin{tabular}{lllllll}
\hline Parameter & CD & $15 \%$ BLM & $30 \%$ BLM & $45 \%$ BLM & SEM & PROB \\
\hline Albumin $(\mathrm{g} / \mathrm{dl})$ & 3.87 & 3.60 & 3.65 & 4.46 & 0.10 & 0.50 \\
Alkaline phosphatase $(\mathrm{U} / \mathrm{L})$ & 54.71 & 51.02 & 48.48 & 51.44 & 4.90 & 0.98 \\
Bilirubin $(\mathrm{mg} / \mathrm{dl})$ & 2.31 & 2.47 & 2.61 & 2.25 & 0.16 & 0.89 \\
Cholesterol $(\mathrm{mg} / \mathrm{dl})$ & 165.14 & 152.72 & 160.36 & 172.50 & 4.60 & 0.45 \\
Creatinine $(\mathrm{mg} / \mathrm{dl})$ & 2.86 & 1.32 & 1.86 & 1.36 & 0.45 & 0.57 \\
Globulin $(\mathrm{g} / \mathrm{dl})$ & 3.08 & 2.70 & 2.71 & 2.86 & 0.28 & 0.96 \\
Total glucose $(\mathrm{mg} / \mathrm{dl})$ & $141.78^{\mathrm{a}}$ & $123.20^{\mathrm{ab}}$ & $113.70^{\mathrm{b}}$ & $113.59^{\mathrm{b}}$ & 4.09 & 0.04 \\
Total protein $(\mathrm{g} / \mathrm{dl})$ & 6.95 & 6.30 & 6.36 & 6.32 & 0.28 & 0.81 \\
Urea $(\mathrm{mg} / \mathrm{dl})$ & 33.67 & 31.00 & 28.33 & 26.33 & 1.60 & 0.45 \\
\hline
\end{tabular}

$\mathrm{a}, \mathrm{b}, \mathrm{c}, \mathrm{d}$ : Means within each row with different superscript are significantly different $(\mathrm{p} \square 0.05)$

The mean serum glucose of animals fed $30 \%$ BLM and 45\% BLM diets were significantly $(\mathrm{P}<0.05)$ lower than that of animals on $\mathrm{CD}$ diets. Animals on control diet had the highest level of total protein which is not significantly $(\mathrm{P}>0.05)$ different from others. The Serum urea values obtained in this study were in line with that of 20.07-30.04 mg/dl recorded by Okoruwa and Agbonlahor (2014) and 18.17-35.17 $\mathrm{mg} / \mathrm{dl}$ reported by Odoemelam et al. (2014) but lower than 32.25-37.30 mg/dl and 37.9 $\mathrm{mg} / \mathrm{dl}$ reported by Ikhimioya and Imasuen (2007) and Opara et al. (2010) respectively. Averagely lower blood urea concentration may be an indicator of better protein quality (Eggum, 1970) while high level of serum urea has been attributed to excessive tissues protein catabolism associated with protein deficiency (Oduye and Adadevoh, 1976). 


\section{Haematological and biochemical profiles of WAD goats fed bitter leaf (Vernonia amygdalina)}

The serum albumin levels in the study were within the range of 3.90-4.45 g/dl reported for WAD goats by Yusuf et al. (2012) but higher than the range of 2.98-3.43 g/dl and $2.8 \mathrm{~g} / \mathrm{dl}$ reported by Okoruwa and Agbonlahor (2014) and Opara et al. (2010), respectively. Increase in serum albumin above normal indicates dehydration, impairment in the function of liver, kidneys and digestive system while low albumin suggests poor clotting ability of blood (Robert et al., 2000) and reduction in disease fighting ability of the animal body system which could lead to high mortality (Iheukwumere et al., 2005). Alkaline phosphatase (ALP) levels obtained in this study were within the range 30.73-79.18 $\mathrm{U} / \mathrm{L}$ reported by Ikhimioya and Imasuen (2007). Values within this range suggest high quality protein in the diet fed as reported by Akinmutimi (2004). Opara et al. (2010) reported higher value of 63.20 U/L. According to Zilva and Pannall (1984), normal enzyme level in serum is a reflection of a balance between synthesis and their release, as a result of the different physiological processes in the body. Guyton (1991) observed that ALP level in the blood is usually a good indicator of bone formation since osteoblasts secrete large quantities of this enzyme. Thus since the diets in this study did not differ from the control diet (CD), it may be deduced that BLM under study did not adversely disrupt the activity of these osteoblasts. Serum bilirubin levels reported in this study were higher than $2.27 \mathrm{mg} / \mathrm{dl}$ of non infected goats reported by Sanni et al. (2013). Bilirubin is a pigment produced primarily in the liver and associated with breakdown of hemoglobin from red blood cells stored in gall bladder as a component of bile. Increase in bilirubin indicates increase red blood cell destruction or decreased bile flow through liver. Result of serum cholesterol (mg/dl) was in agreement with range reported by Pampori (2003), but higher than the values reported by Damir (2001); Taiwo and Ogunsanmi (2003) and Ikhimloya and Imasuen (2007). The serum cholesterol levels depend on the amount and quality of protein offered in the feed (Esonu et al., 2001). This means that the protein provided by the control diet and different bitter leaf meal inclusion was enough and of good quality to meet the nutritional needs of the animals. Creatinine level did not differ between the diets in this study, an indication that the treatment diets have no effect on this variable. This explains the effectiveness of body mass function in goats and fewer waste products in the muscle of the goats. However, compared to values reported for apparently healthy Marwari goats (Tanwar et al., 2000) and West African Dwarf goats (Ikhimioya and Imasuen, 2007; Okoruwa and Agbonlahor, 2014), high serum creatinine values were obtained in this study. All the experimental goats were within the range of 2.7-4.4 g/dl for globulin (Merck, 2011) and 2.33-3.63 g/dl reported by (Ukpadi, 2007) but higher than $2.4 \mathrm{~g} / \mathrm{dl}$ reported by Opara et al. (2010). The diets in this study did not significantly affect globulin levels in the serum of the goats thus indicating the safety of these BLM as supplements for goats. This is important because decreased globulin below the normal level leads to weak immune system of the body and consequently decreased disease fighting ability of the animal's body which leads to high mortality rates in the event of disease outbreak (Iheukwumere et al., 2005). The mean serum glucose of animals fed $30 \%$ BLM and $45 \%$ BLM diets were significantly $(\mathrm{P}<0.05)$ lower than that of animals on CD diets. Serum glucose level is an indicator of carbohydrate metabolism in high energy diets (Coles, 1974). Glucose level which is lower than normal range is an indication of hypoglycemia while higher levels are indication of hyperglycemia. The observed hypoglycemia effect is a possible 


\section{Olosunde, Odeyinka and Oyedele}

pointer that the inclusion of BLM at $30 \%$ and $45 \%$ can impair or disrupt the pathway for glucose metabolism. Serum proteins are important in osmotic regulation, immunity and transport of several substances in the animal body (Jain, 1986; Ikhimioya and Imasuen, 2007). However, in this experiment, animals on control diet had the highest level of total protein which is not significantly $(\mathrm{P}>0.05)$ different from others. Besides, the statistically nonsignificant $(\mathrm{P}>0.05)$ difference between the control and other diets may be related to the findings of Tewe and Maner (1980) that serum protein is related to the availability of protein in diets for utilization. The values obtained from this study were higher than 3.33-5.52 g/dl reported by (Odoemelam et al., 2014) but within the range of 6.4-7.00 $\mathrm{g} / \mathrm{dl}$ reported by (Amalendu, 2006).

\section{Conclusion}

The study showed that feeding of bitter leaf meal at different levels had no adverse effect on the haematological and biochemical profiles of West African dwarf goats fed graded levels of bitter leaf meal except in the reduction of serum glucose in animals fed above $15 \%$ bitter leaf meal.

\section{References}

Ahmed, I., Gohar, A., Ahmed, N. and A h m e d , M . 2009 . Haematological profile in cyclic and non- cyclic and Endometritic Cross breed Cattle. International Journal of Agriculture and Biology 27:83-91.

Aikhumobhoge, P. U. and Orheruata, A. M. 2006. Haematological and blood biochemical indices of WAD goat vaccinated against PPR. African Journal of Biotechnology 5:734-448.

Akinmutimi, A. H. 2004. Evaluation of sword bean Canavalia gladiata as an alternative feed resource for broiler chickens. Ph.D. Thesis, Michael Okpara University of Agriculture Umudike, Nigeria.

Aletor, O., Oguntokun, M. O. and Aletor, V.A. 2002 . Proximate composition, energy content and mineral profile of some conventional and under-utilized fibrous feed resources. Proceedings of $27^{\text {th }}$ Annual Conference, Nigeria Society for Animal Production (NSAP), March 17 - 21st, Federal University of Technology, Akure, Nigeria pp. $135-138$.

Amakiri, S. F. 1981. Hematological Studies of various indigenous and exotic breeds of goats and their F1 crosses in Nigeria. Bulletin of Animal Health Production African 29:377-380.

Amalendu, C. 2006. Textbook of Clinical Veterinary Medicine. Kalyani publishers, New Delhi, India. Pp. 421-446.

AOAC 2000. Association of official analytical chemists. Official methods of Analysis 16th edition. Washington D.C USA.

Bawala, T. O., Aina, A. B. J., Onwuka, C. F. I., Oni, A. O., Adebisi, Y. and Alli, M. A. 2008. Studies on performance of sheep fed sugarcane tops supplemented with varying levels of Leucaena Leucocephala foliage In: Proceedings of $33^{\text {rd }}$ Annual Conference of Nigerian Society of Animal Production held 17-20 $0^{\text {th }}$, March 2008. Printed by Unique concept, Ibadan, Nigeria, pp 583586. ISBN: 1596-5570.

Bonsi, M. L. K., Osuji, P. O., Tuah, A. K. and Umunna, N. N. 1995. Vernonia amygdalina as a supplement to teff straw (Eragrostis tef) fed to Ethiopian 
Menz sheep. Agroforestry in Sustainable Agricultural System, 31:229-241.

Coles, E. B. 1974. Blood glucose determination. In: Veterinary Clinical Pathology, 2nd edn. M.B. Saunders Company, West Washington Square, Philadelphia, pp 272-274.

Damir, Z. 2001. Some biochemical parameters in the blood of grazing German improved fawn goats from Istria, Croatia. Veterinarski Arhiv 71(5): 237-244.

Daodu, M. O. and Babayemi, O. J. 2009. Utilization of Some Edge-Row Plants as Forage in Nigeria. Pakistan Journal of Nutrition, 8 (8): 1269-1274.

Eggum, B. O. 1970. Blood ureameasurement as a technique for assessing protein quality. Britain Journal of Nutrition, 24: 985-988.

Esonu, B. O., Emenalom, O. O., Ododibie, A. B. I., Herbbert, U., Ekpor, C. F., Okoli I. C. and Ihuekwumere, F. C. 2001. Performance and blood chemistry of weaner pigs fed raw mucuna beans (velvet bean) meal. Tropical Animal Production, 4: 49-54.

Fajemisin A. N., Alokan J. A., Onibi G. E., Aro S. O. and Fadiyimu A. A. 2009. Response of West African dwarf ewes fed Vernonia amygdalina leaf meal in cassava starch residue - based diet. Proceedings Nigeria Society for Animal Production (NSAP), $34^{\text {th }}$ Annual Conference March 15 18th, Uyo, Nigeria. pp 480 - 482.

Farombi, E. O. and Owoeye, O. 2011. A n t i o x id a t i ve a nd Chemopreventive properties of $\mathrm{V}$. amygdalina. International Journal of Environmental Research and Public Health. 8 (6) 2533-2555.
Hassan, M. M., Hoque, M. A., Islam, S. K. M. A., Khan, S. A., Hossain, M. B. and Banu, Q. 2012 . Efficiency of anthelmintics against parasitic infections and their treatment effect on production and blood indices in Black Bengal goats in Bangladesh. Turkish Journal of Veterinary and Animal Sciences 30 (4): 400-408.

Iheukwumere, F. C., Okoli, I. C., Anyanwu, G. A. and Esonu, B. O. 2005. Growth performance, haematology and serum biochemical constituents of grower rabbits fed Microdesmis puberula, Hook.-Euphorbiaceae. Animal Production Research Advances, 1: 24-31.

Ikhimioya, I. and Imasuen, J. A. 2007. Blood profile of West African dwarf goats fed Panicum maximum supplemented with Afzelia Africana and Newbouldia laevis. Pakistan Journal of Nutrition, 6: 79-84.

Imasuen, J. A. 2012. Effect of Different Management Environment on Hematological Perfomance in West African Dwarf(WAD) Goats. Journal of Research in Forestry, Wildlife and Environment. Volume 4 No. 2 .

Isidahomen, C. E., Njidda, A. A. and Olatunji, E. A. 2012. Heat tolerant traits among local and exotic chickens in southern Nigeria (2012). IOSR. Journal of Agriculture and Veterinary Science, 1(6): 31-36.

Jain, N. C. 1986. Schalm's Veterinary Hematology. $4^{\text {th }}$ Edition Lea and Babings, Phiadelphia, pp. 208-224.

Jain, N. C. 1993. Physiology of blood with some comments on response to disease. International Journal of Animal Science, 8, 195-231. 


\section{Olosunde, Odeyinka and Oyedele}

Jean, P. 1992. Animal Production in the Tropics and Subtropics. The Macmillan Press Ltd. London and Basingstoke $1^{\text {st }}$ Edition. Pg. 517.

Merck, 2011. Merck Sharp and Dohme Corporation, a subsidiary of Merck \& Co., Inc. Whitehouse Station, NJ, USA.

Nwakpu, P. E and Uchewa E. N. 2014. Effect of feeding Gmelina arborea leaves supplemented with aspergillus treated rice husk on growth performance and haematology of West African Dwarf goat (WADG). Global Journal of Agriculture and Food Sciences Research Vol.1, No.2, pp.53-59.

Odoemelam, V. U., Ahamefule, F. O., Ibeawuchi, J. A. and Ahiwe, E. U. 2014 . Haematology and Biochemical Indices of West African Dwarf (WAD) Bucks Fed Panicum maximum and Bambara nut (Vigna subterranean) Seed Meal Supplemented Diets. Nigerian Journal of Animal Science, 16(1): 106-115.

Oduye, O. O. and Adadevoh, B. K. 1976. Biochemical values of apparently normal Nigerian Sheep. Nigerian Veterinary Journal 5(1): 43-50.

Okoli, I. C., Anunobi, M. O., Obua, B. E. and Enemuo, V. 2003. Studies on selected browses of South Eastern Nigeria with particular reference to their proximate and some endogenous anti-nutritional constituents. Livestock Research for Rural Development, Volume 15 , Number 9.

Okoruwa, M. I. and Agbonlahor, I. 2014. Effect of Combining Yam Peels with Cowpea Husk on Nitrogen Metabolism and Serum Biochemical Parameters of West African Dwarf Goats fed Guinea
Grass. Journal of Biology, Agriculture and Healthcare, 4(24): 105-110.

Okoruwa, M. I. and Ikhimioya, I. 2014. Haematological Indices and Serum Biochemical Profiles of Dwarf Goats Fed Elephant Grass and Varying Levels of Combined Plaintain with Mango Peels. American Journal of Experimental Agriculture, 4, 6.

Olubunmi, P. A., Oyedele, O. J. and Odeyinka, S. M. 2005. Effect of feeding soybean milk residue, cowpea seed waste and corn starch residue on blood parameters, rectal temperature and carcass quality of West African Dwarf Goats. Indian Journal of Animal Sciences 75(5): 534-538.

Oluyeni, T. B., Farinu, G. O., Togun, V. A., Adedeji, O. S. and Aderinola, A. O. 2006. Performance and haematological characteristics of weaner pigs fed wild sunflower (Tithonia diversifolia hemsl. A. Gray) leaf meal. Journal of Animal and Veterinary Advances. 5(6): 499-502.

Opara, M. N., Udevi, N. and Okoli, I. C. 2010. Haematological Parameters and Blood Chemistry of Apparently Healthy West African Dwarf (Wad) Goats in Owerri, South Easthern Nigeria. New York Science Journal 3(8): 68-72.

Owen, O. J. 2011. Proximate Composition, Energy Content and Mineral Profile of Vernonia amygdalina (Bitter Leaf) Meal. Advances in Food and Energy Security 1 (2011) 36-39.

Pampori, Z. A. 2003. Field Cum Laboratory Procedure in animal health care. Daya publishing house, New Delhi, India, pp 172182. 
Robert, K. M., Daryl, K. G., Peter, A. M. and Vector, W. R. 2000. Mayers Biochemistry, 25 ${ }^{\text {th }}$ Edn. McGrow Hill, New York, pp. $763-765$.

Sanni, T. M., Onasanya, G. O., Adefenwa, M. A., Yakubu, A., Ikeobi, C. O. N., Adebambo, $O$. A., Talabi, A. O., Ozoje, M. O., Wheto, M., Takeet, M., Peters, S. O., Donato, M. D., Thomas, B. N. and Imumorin, I. G. 2013. Molecular Diagnosis of Subclinical African Trypanosoma vivax Infection and Association with Physiological Indices and Serum Metabolites in Extensively Managed Goats in the Tropics. Open Journal of Veterinary Medicine, 3: 39-45.

SAS 2008. SAS User's Guide Statistics, SAS Inc. Cary., North Carolina, 2008 edition.

Sugano, M., Goto, S., Yaouhala, K., Hashinmoto, V., Matsno, T. and Kimoto, M. 1993. Cholesterol lowering activity of various undigested fractions of soybean proteins in rats. Journal of Nutrition 120(9): 97798.

Taiwo, V. O. and Ogunsanmi, A. O. 2003. Haematology, plasma, whole blood and erythrocyte biochemical values of clinically healthy captive-reared grey duiker and West African dwarf sheep and goats in Ibadan, Nigeria. Israel Journal of Veterinary Medicine 58(2\&3): 57-61

Tanwar, R. K., Tinna, N. K., Gahlot, A. K. and Sharma, S. N. 2000. Biochemical profile of clinical ketosis in goats. In: Proceedings of the 7th International Conference on Goats by the International Goat Association (IGA), 15-21 May 2000, Toulouse, France, pp: 306307.
Tewe, O. O. and Maner, J. H. 1980. Cyanide, protein and iodine interaction in the physiology and metabolism in rats. Food Chemistry, 9: 95-204.

Ukpadi, U.H. 2007. Evaluation of Mucuna seed meal based diets for goat production in south eastern Nigeria. Ph.D. dissertation. Michael Okpara University of Agriculture Umudike, Nigeria.

Yusuf, A. O., Oyebanji, O. A., Yusuf, D. A., Ekunseitan, K. A., Adeleye, O. S., Sowande and Fasae, O. A. 2012. Blood profile of West African dwarf goats fed Panicum maximum supplemented with Newbouldia laevis leaves. Bulletin of Animal Health Production African 60: 493 - 502.

Zilva, J. F. and Pannall, P. R. 1984. Clinical Chemistry in Diagnoses and Treatment, 4th Ed. Lloyd-Luke Medical Books Ltd., London, $185 \mathrm{pp}$.

Received: $27^{\text {th }}$ August, 2020 Accepted: $21^{\text {st }}$ November, 2020 